DOI https://doi.org/10.30525/978-9934-588-86-0.11

\title{
SOME PROBLEMS OF RISK-MANAGENET IN SEA PORT ACTIVITY
}

\section{Balobanov O. O., Postan M. Ya.}

\section{INTRODUCTION}

In sea port activity the lot of different risks may arise related to operational activity of some participants: carriers, charterers, operators of terminals, surveying companies, insurance companies, custom service and other. That is why, for avoiding or mitigation or these risks the scientific and/or organizational methods must be applied based on information technologies use. In this chapter, two typical problems related to risk-management in sea port activity are considered in details. They both are related to cargo transshipment.

First problem concerns the risk control in surveying company activity. The method is proposed for risk insurance arising under inspection by surveying company (surveyor) of general cargo technical state before its loading on a ship. It is supposed that inspection is based on the methods of statistical sampling theory for the purpose of defected cargo units determination. That is, from general set of cargo units a part of them has been chosen for providing the total inspection by the surveyor. In such situation the surveyor faces the risk of lot of defected cargo units among those which were out of the total check. For this risk reduction the value of surveyor's profit is evaluated for two kinds of decision making: (1) risk insurance and (2) rejection of risk insurance. Criterion of insurance expediency is based on determination of such sample plan that maximizes mean surveyor's profit under comparison of mean profit for both kinds of decision making. The determination of sample plan is reduced to a discrete non-linear optimization problem.

Second problem is connected with possible risk of containers damage under they loading/unloading and it is related to evaluation of insurance expediency of stevedoring company's responsibility for cargo safety under its loading or unloading.

\section{METHOD OF SUBSTANTIATION OF SURVEYING COMPANY RISK INSURANCE}

A sea commercial port, as the logistics center or key link of logistics supply chain, is the place where the vector-interests arises of international sea trade subjects, that is participants of supply chains. In other words, the commercial interests of these subjects (i.e. cargo-owners, stevedoring 
companies, transport companies, etc.) come into collisions. The resolution of above collisions is possible via the legislation and/or contract norms or via commercial methods. This way provides preservation of stability within supply chains. However, when the collisions are regularly arising in practice then the subjects of supply chain are forced to search the other methods of their prevention.

The effective way of this problem solution is identification, classification of risks and their control. The set of organizational and scientific methods of risk mitigation or avoiding is called risk-management.

Strictly speaking, a risk is always a potential possibility only but its consequences are pecuniary. In commercial sea practice the only one way of risk control is possible,

namely, the control of possible consequences of risk events, avoiding or mitigating them via surveying, insurance or other service ${ }^{1}$.

Often, in a port's practice, when right of cargo owning transfers from one businessman to another (for example, from railway to port's terminal operator, from terminal's operator to ship owner, etc.) some risks and conflicts may appear concerning the technical state of cargo (its defects), its quantitative or qualitative characteristics. The possible risks of responsibility related to cargo preservation under its transshipment, transportation, and storage are sufficiently determined with the quality of execution by a businessman his professional dues. For example, in the activity of port terminal's operator different risks may occur connected with technical state of cargo transshipped from surface transport to ships. It is impossible for operator in practice to organize control of technical state of all cargo party, therefore he takes on yourself risk responsibility before cargo owner and/or charterer for loading on a ship defected units of cargo (if it is general cargo). This risk operator may decrease with the help of surveying company which must try this risk decrease due to careful inspection of a more or less big part of cargo and preparation of accurate information to operator in so-called survey act.

The problem of mentioned risk mitigation with the different organizational-economical methods is very actual for theory and practice of maritime business.

Note that it is needed to differ risks of port's operator (stevedor) responsibility for cargo before cargo owner or forwarder (he represents cargo owner) and risks of surveyor's professional activity before terminal's operator who engaged him for the purpose of cargo technical (or physical) state evaluation. They are connected but essentially differ from each other by their juridical nature. Therefore, a stevedor can't shift off his own risk on surveyor.

${ }^{1}$ Balobanov A. O. (2010) Organizacionno-pravovye aspekty syurvejerskoj deyatelnosti [Organizational-legislative aspects of surveying activity]. Odessa: Feniks. (in Russian) 
He can and even must receive from surveyor information about physical state of cargo and use it for decreasing of his risk. The insurers, by their juridical nature, must take the risks of insured upon oneself. At the same time, a stevedor and other participants of cargo business must insure their own risks, and for surveyor it will be insurance indemnity of his professional risk, that is, his incorrect assessment of cargo physical state.

As long as the execution of technological operations concerning the loading/unloading and storage of cargo in sea port has flow-like or mass-like character, there arises some analogy with mass-like production in industrial enterprise, where the methods of statistical sample control (SSC) have been successfully applied for a long period for the purpose of finished product's quality control ${ }^{2,3,4}$. However, in sea transport enterprises' activity the SSC have not yet due applications in spite of the marine insurance has almost 200 years history ${ }^{5}$. The possibility of SSC application for quality control of cargo transshipping in sea ports was shown firstly in the article ${ }^{6}$ where the method of optimal sample plan finding for physical state of cargo control by a surveying company under loading/unloading of general cargo on/from a ship. Further development of this approach was given in the works ${ }^{7,8}$. At the same time, in the cited works was not considered the possibility of risks of surveying company responsibility's mitigation for loading/unloading of defected cargo with the help of insurance. Note that the problem of risks insurance related to professional responsibility of sea transport business has been investigated

${ }^{2}$ Belyaev Yu. K. (1975) Veroyatnostnye metody vyborochnogo kontrolya [Probabistic method of sampling control]. Moscow: Nauka. (in Russian)

${ }^{3}$ John P.W.M. (1990) Statistical Methods in Engineering and Quality Assurance. New York: Wiley.

${ }^{4}$ Juran J. M., Gryna F. M. (1993) Quality Planning and Analysis, $3^{\text {rd }}$ ed., New York: McGraw-Hill.

${ }^{5}$ Rose F. D. (2012) Marine Insurance: Law and Practice (2012) 2nd Ed., London: Informa Law.

${ }^{6}$ Postan M. Ya., Podchinok I. V. (2004) Ob odnom metode postroeniya optimalnogo plana vyborochnogo kontrolya sostoyaniya gruza $\mathrm{v}$ portu [On a method of optimal sample plan for cargo technical state finding in port]. Methods and Means of Transportation Systems Development. Collection of Scientific Papers. Odessa: Odessa National Maritime University. Issue 7, pp. 5-17. (in Russian)

7 Podchinok I. V. (2005) Sravnitelnyj Analiz Razlichnyh Planov Vyborochnogo Kontrolya Sostoyaniya Gruza v Portu [Comparative Analyses of Different Plans of Sampling Control of Cargo State in Port]. Methods and Means of Transportation Systems Development. Collection of Scientific Papers. Odessa: Odessa National Maritime University. Issue 9, pp. 113-122. (in Russian)

8 Moskvichenko I. M., Stadnik V. G. (2013) Statystychni Metody Vybirkovogo Kontrolyu Stanu Vantazhu v Portu [Statistical Methods of Sample Control of Technical State of Cargo in Port]. Technology Audit and Production Reserves. № 5/3 (13), pp. 30-33. (in Ukrainian) 
insufficiently well in special literature devoted to marine and transport insurance. From some works in this direction the article ${ }^{9}$ may be pointed out, where a method for assessment of expediency of a containers damage risk insurance under their loading/ unloading at port's terminal is proposed. In the article $^{10}$ the method of risk assessment related to a berth damage under ship's loan during its moorage is proposed which is based on the queueing theory application.

The aim of this Section is the further development of results of the works $^{11,12,13}$ for the purpose of the methods development for expediency assessment of a surveying company risk insurance in sea port. The above risk is related to possible loading on board of ship too big number of defected cargo units (e.g. containers) in spite of previous sampling detection of all parcel of goods for the purpose the defected cargo units' detection. It is quiet clear that total detection of all parcel of goods is impossible because of limited time and too big expenses.

To achieve this aim the following tasks must be previously solved:

1) to make a formalized description of sample control procedure of parcel of goods intended for loading on ship in terms of SSC theory;

2) to evaluate the main kinds of surveying company costs related to sampling control organization including the cost related to risk of too much number of undetected defected units of loaded on ship cargo;

9 Postan M. Ya., Balobanov A. O. (2011) Method of Evaluation of Insurance Expediency of Stevedoring Company's Responsibility for Cargo Safety. Methods and Algorithms in Navigation and Safety of Sea Transportation. Eds. A. Weintrit and T. Neumann. CRC Press, pp. 33-36.

${ }^{10}$ Postan M. Ya., Poizner M. B. (2013) Method of Assessment of Insurance Expediency of Quay Structures' Damage Risks in Sea Ports. Marine Navigation and Safety of Sea Transportation. Maritime Transport and Shipping. Eds. A. Weintrit, T. Neumann. Boca Raton-London-New York-Leiden: CRC Press, pp. 123-127.

11 Podchinok I. V. (2005) Sravnitelnyj Analiz Razlichnyh Planov Vyborochnogo Kontrolya Sostoyaniya Gruza v Portu [Comparative Analyses of Different Plans of Sampling Control of Cargo State in Port]. Methods and Means of Transportation Systems Development. Collection of Scientific Papers. Odessa: Odessa National Maritime University. Issue 9, pp. 113-122. (in Russian)

12 Postan M. Ya., Podchinok I. V. (2004) Ob odnom metode postroeniya optimalnogo plana vyborochnogo kontrolya sostoyaniya gruza $\mathrm{v}$ portu [On a method of optimal sample plan for cargo technical state finding in port]. URL: Methods and Means of Transportation Systems Development. Collection of Scientific Papers. Odessa: Odessa National Maritime University. Issue 7, pp. 5-17. (in Russian)

13 Moskvichenko I. M., Stadnik V. G. (2013) Statystychni Metody Vybirkovogo Kontrolyu Stanu Vantazhu v Portu [Statistical Methods of Sample Control of Technical State of Cargo in Port]. Technology Audit and Production Reserves. № 5/3 (13), pp. 30-33. (in Ukrainian) 
3) to express the above mentioned cost through the control parameters the numbers of cargo units subjected to detection of physical state of cargo (i.e. sampling plan);

4) to formulate the restrictions for the sampling plan;

5) to formulate the corresponding stochastic optimization problem for sampling plan finding;

6) to formulate the criterion of risk of too much number of defected cargo units loaded on ship insurance expediency.

Let us consider a port's terminal for general cargo (containers) loading on the ship. Before of cargo loading beginning the charterer (and carrier, as well) must have most objective information concerning physical state of cargo. It is important for him (them) to restrict his (they) responsibility for cargo preservation during the voyage because carrier must pass cargo to cargo receiver (s) in port of destination in due state.

With the aim of above information receiving a carrier may resort to the help of independent surveying company that can realize a sampling control of cargo state. In result of surveying a master of ship get corresponding report which contents information about possible defects of cargo and this report is the official document under mutual calculations between carrier and cargo owner at port of destination.

Taking into account that total inspection all cargo to be loaded on the ship is impossible due to temporal and financial restrictions then a situation is arising similar to those when the method of SSC is applying in industrial production $^{14,15,16}$. In the situation described above a risk arises of surveyor's professional activity related to loading on the ship too much defected cargo units in result of impossibility providing more accurate and full inspection of all cargo's technical state. In the case when a surveyor evaluates possibility of this risk insurance for given cargo party then he faces the dilemma: to insure or not to insure this risk?

Below, we will give the formalized description of sampling control of technical state of cargo in the terms of SSC theory.

Let us there are $R$ types of general cargo to be loaded on the ship in quantities $N_{1}, N_{2}, \ldots, N_{R}$ correspondingly. It is assumed also that probability are known that arbitrary cargo unit of the $r$-th type is in defected state equals to $p_{r}$. This probability may be determined by statistical methods on the basis of statistical

${ }^{14}$ Belyaev Yu. K. (1975) Veroyatnostnye metody vyborochnogo kontrolya [Probabistic method of sampling control]. Moscow: Nauka. (in Russian)

${ }^{15}$ John P.W. M. (1990) Statistical Methods in Engineering and Quality Assurance. New York: Wiley.

${ }^{16}$ Juran J. M., Gryna F. M. (1993) Quality Planning and Analysis, $3^{\text {rd }}$ ed., New York: McGraw-Hill. 
data for previous period. In SSC theory the distribution of defected units number $D_{r}$ of the $r$-th type in all party of $N_{r}$ units is taken binomial, that is

$$
\mathbf{P}\left\{D_{r}=k\right\}=C_{N_{r}}^{k} p_{r}^{k} q_{r}^{N_{r}-k}, k=0,1, \ldots, N_{r},
$$

where $q_{r}=1-p_{r}$. This assumption is consequence of hypothesis about mutually independent inspections of cargo units technical state. For determination of statistical (expected) realizations of random variables $D_{1}$, $D_{2}, \ldots, D_{r}$ (we assume that they are independent from each other) the surveying company provides the full inspection of $n_{r} \leq N_{r}$ units of the $r$-th type (that is, $n_{r}$ is sample volume). The number of defected cargo units among the $n_{r}$ inspected we denote $d_{r}$. From probability theory is known that conditional distribution of random variable $d_{r}$ under condition $D_{r}=k$ is hypergeomertic, that is

$$
\mathbf{P}\left\{d_{r}=i \mid D_{r}=k\right\}=\frac{C_{k}^{i} C_{N_{r}}^{n_{r}-i}-k}{C_{N_{r}}^{n_{r}}}, k=0,1, \ldots, N_{r} ; i=0,1, \ldots, \min \left(n_{r}, k\right) .
$$

In the book ${ }^{17}$ it is shown that unconditional distribution of random variable $d_{r}$ is binomial as well, i.e.

$$
\mathbf{P}\left\{d_{r}=k\right\}=C_{n_{r}}^{k} p_{r}^{k} q_{r}^{n{ }^{-k}}, k=0,1, \ldots, n_{r} .
$$

From (1), (2) we find out the joint distribution of mutually depended random variables $D_{r}$ и $d_{r}$ (omitting the intermediate calculations):

$$
\begin{gathered}
\mathbf{P}\left\{D_{r}=k, d_{r}=i\right\}=C_{N_{r}-n_{r}}^{k-i} p_{r}^{k} q_{r}^{N_{r}-k}, \\
k=0,1, \ldots, N_{r} ; i=0,1, \ldots, \min \left(k, n_{r}\right) .
\end{gathered}
$$

Note, that $D_{r}-d_{r}$ is the random number of loaded on the ship cargo units of the $r$-th type with defects. Namely, these cargo units of the $r$-th type with defects will be unloaded from ship in port of destination. If in the port of

${ }^{17}$ Belyaev Yu. K. (1975) Veroyatnostnye metody vyborochnogo kontrolya [Probabistic method of sampling control]. Moscow: Nauka. (in Russian) 
destination the surveying inspection will be organized by cargo receiver there may arise the risk of carrier (and charterer, as well) for transferring part of cargo in defected state.

The carrier must pay to receiver of cargo for these defected cargo units and afterword to forward account to surveyor in the port of loading in order socalled regressive compensation. If carrier pays penalty $\pi_{r}$ to cargo receiver for cargo unit of the $r$-th kind with detected defect in the port of unloading then the total sum of payment is

$$
\sum_{r=1}^{R} \pi_{r}\left(D_{r}-d_{r}\right)
$$

Finally, exactly this sum surveyor would pay to a charterer in the port of loading. Therefore, in this situation, surveyor may consider the possibility insurance of risk to loss the money (4). Assume that when he decides to insure this risk according to policy he must to pay to insurer the insurance premium $c$. Besides, we assume that in the case of losses the insurer will refund the penalty (4) to surveying company. However, the problem is that at moment of policy signing the value (4) is not known exactly. But it is possible to evaluate the mean value and variation of random variable (4). That is why here a risk arises connected with insurance premium $c$ determination. An insured person will pay this premium to insurer according to insurance policy after its signing. It is naturally that insured person don't wish to increase the value $c$, that is $c$ must not deviate from real value of expression (4) significantly.

Let us evaluate the size of surveying company's profit in result of cargo inspection in two cases: (1) it insure its risk and (2) it dose not insure its risk. If $\alpha_{r}$ denotes the profit of surveying company in result of detection of cargo unit of the $r$-th kind then in the case of risk insurance the profit of company is

$$
\Pi_{\text {ins }}=\sum_{r=1}^{R} \alpha_{r} n_{r}-c .
$$

Otherwise, its profit is

$$
\Pi_{\text {nins }}=\sum_{r=1}^{R}\left[\alpha_{r} n_{r}-\pi_{r}\left(D_{r}-d_{r}\right)\right] .
$$

From the equalities (1), (3) and (6) it follows that the mathematical expectation and variation of profit in the case of risk noninsurance are 


$$
\begin{gathered}
\mathbf{M} \Pi_{\text {nins }}=\sum_{r=1}^{R}\left[\alpha_{r} n_{r}-\pi_{r} p_{r}\left(N_{r}-n_{r}\right)\right] . \\
\mathbf{D} \Pi_{\text {nins }}=\sum_{r=1}^{R} \pi_{r}^{2} p_{r} q_{r}\left(N_{r}-n_{r}\right) .
\end{gathered}
$$

Here, we use the following equality $\left(\mathrm{See}^{18}\right)$ :

$$
\mathbf{D}\left(D_{r}-d_{r}\right)=p_{r} q_{r}\left(N_{r}-n_{r}\right) .
$$

It is naturally to assume that decision concerning insurance of risk will be substantiated if with high probability the following condition will be valid (see (5), (6))

$$
\Pi_{\text {нстр }}=\sum_{r=1}^{R}\left[\alpha_{r} n_{r}-\pi_{r}\left(D_{r}-d_{r}\right)\right]<\Pi_{c m p}=\sum_{r=1}^{R} \alpha_{r} n_{r}-c .
$$

Mathematically this condition may be written by the following way:

$$
\mathbf{P}\left\{\sum_{r=1}^{R} \pi_{r}\left(D_{r}-d_{r}\right)>c\right\} \geq 1-\varepsilon,
$$

or

$$
\mathbf{P}\left\{\sum_{r=1}^{R} \pi_{r}\left(D_{r}-d_{r}\right) \leq \mathcal{C}\right\} \leq \varepsilon,
$$

where $\varepsilon$ is the given small probability. Applying to (9) one of the modifycation of Tchebyshev inequality ${ }^{19}$, and taking into account (7),(8) we find

${ }^{18}$ Postan M. Ya., Podchinok I. V. (2004) Ob odnom metode postroeniya optimalnogo plana vyborochnogo kontrolya sostoyaniya gruza $\mathrm{v}$ portu [On a method of optimal sample plan for cargo technical state finding in port]. Methods and Means of Transportation Systems Development. Collection of Scientific Papers. Odessa: Odessa National Maritime University. Issue 7, pp. 5-17. (in Russian)

19 Feller W. (1984) Vvedenie v Teoriyu Veroyatnostej i Ee Primeneniya [An Introduction to Probability Theory and Its Application]. V. 2. Moscow: Mir. (in Russian) 


$$
\mathbf{P}\left\{\sum_{r=1}^{R} \pi_{r}\left(D_{r}-d_{r}\right) \leq c\right\} \geq \frac{\left[\sum_{r=1}^{R} \pi_{r} p_{r}\left(N_{r}-n_{r}\right)-c\right]^{2}}{\left[\sum_{r=1}^{R} \pi_{r} p_{r}\left(N_{r}-n_{r}\right)-c\right]^{2}+\sum_{r=1}^{R} \pi_{r}^{2} p_{r} q_{r}\left(N_{r}-n_{r}\right)} .
$$

Then from (9) we get the following inequality

$$
\frac{1-\varepsilon}{\varepsilon}\left[c-\sum_{r=1}^{R} \pi_{r} p_{r}\left(N_{r}-n_{r}\right)\right]^{2} \leq \sum_{r=1}^{R} \pi_{r}^{2} p_{r} q_{r}\left(N_{r}-n_{r}\right) .
$$

In the sea port's practices the time for surveying control is always restricted. If labor productivity of surveyors when they inspect of cargo units of the $r$-th kind equals to $v_{r}$ and total time for sample control must not exceed $T$ then sampling plan must satisfy to condition (under supposition about consequent inspection of all kinds of cargo units)

$$
\sum_{r=1}^{R} \frac{n_{r}}{v_{r}} \leq T
$$

(it is assumed that $\sum_{r=1}^{R} \frac{N_{r}}{v_{r}}>T$ ).

It is naturally that control parameters $n_{1}, n_{2}, \ldots, n_{R}$ satisfy the restrictions:

$$
1 \leq n_{r} \leq N_{r}, r=1,2, \ldots, R \text {. }
$$

In result, the procedure of insurance expediency determination under cargo inspection is derived to the following discrete optimization problem: it is required to find out the plan of sample control $\left(n_{1}, n_{2}, \ldots, n_{R}\right)$ and the value of insurance premium $c$ for the purpose of the function (5) maximization under conditions (10) - (12).

The optimization problem formulated above is nonlinear partly discrete optimization problem. For its solving the standard algorithms in the field of discrete optimization theory may be used ${ }^{20}$.

${ }^{20}$ Saaty T. L. (1970) Celochislennye Metody Optimizacii i Svyazannye s Nimi Problemy [Optimization in integers and related extremal problems]. Moscow: Mir. (in Russian) 


\section{METHOD OF EVALUATION OF INSURANCE EXPEDIENCY OF STEVEDORING COMPANY'S RESPONSIBILITY FOR CARGO}

SAFETY

In operational activity of the stevedoring companies and in practice of

marine insurance, many cases may occur related to the situations of risk. The main of them are listed below:

- damage of a ship's hull or equipment during the loading/unloading;

- cargo package's damage in result of violation of loading/unloading rules or rules of port's mechanisms exploitation;

- damage of cargo in result of violations of rules of its storage at warehouse;

- failures of port's equipment;

- exceeding of a ship's laytime.

Appearance of above events leads to some additional expenditure for the stevedoring company, charterer or cargo owner. As shows the international commercial practice, many stevedoring companies which operate in big seaports insure their responsibility for safe and qualitative transshipment of cargo (within the framework of contract responsibility) ${ }^{21}$.

When the managers of a stevedoring company make decision concerning an insurance of its responsibility for safe transshipment of cargo it is useful and even necessary to apply the methods of probability theory and actuarial mathematics ${ }^{22,23}$. At the same time the standard methods of quantitative evaluation of risk proposed by mathematical risk theory are mainly aimed at insurance companies' profit but not at protection of commercial interests of insured person. Therefore, specifics of seaports operational activity and interrelations between stevedoring company's managers and its clients demand the special methods for actuarial calculations.

The purpose of this Section is working out a method of a risk evaluation of containers damage under their transshipment at a seaport terminal and substantiation of insurance expediency of this risk by a stevedoring company.

Our approach is based on representation of port's container terminal as a queueing system of $\mathrm{GI} / \mathrm{G} / m$ type (that is, system consists of $m$ identical servers-berths in parallel, the ships arriving at terminal are the "customers", infinite waiting room, service discipline is FIFO, that is, moorage of a ship at a free berth occurs according the rule "first in - first out") [16]. The flow of ships is described by model of renewal process, and service time of any ship

${ }^{21}$ Brown R. H. (1985-1993) Marine Insurance: Vol. I. Principles and Basic Practice; Vol. II. Cargo Practice; Vol. III. Hull Practice, London: Witherby Publishers.

${ }^{22}$ Asmussen S. (2001) Ruin Probabilities, World Scientific, Singapore-New Jersey London-Hong Kong: World Scientific.

${ }^{23}$ Grandell J. (1992) Aspects of Risk Theory. Berlin-Heidelberg-New York: Springer. 
(i.e. its loading-unloading time) is random variable with arbitrary distribution function.

We denote:

$\omega(t)$ be a random number of served ships in time interval $(0, t)$;

$\gamma_{k}$ be a random number of containers transshipped on/from the $k$ th ship served in time interval $(0, t)$;

$v_{k}$ be a random number of damaged containers during loading/unloading of the $k$ th ship;

$\Delta_{k i}$ be a random value of damage caused to the $i$ th container loaded on or unloaded from the $k$ th ship (estimated in money).

It is assumed that:

a) the random variables $\gamma_{1}, \gamma_{2}, \ldots$ are independent and identically distributed (i.i.d.) with the discrete distribution

$$
\pi_{M}=\operatorname{Pr}\left\{\gamma_{1}=M\right\}, M=1,2, . ., \quad \sum_{M \geq 1} \pi M^{=1}
$$

b) $v_{1}, v_{2}, \ldots$ are the i.i.d. random variables with the conditional binomial

$$
\text { distribution } \operatorname{Pr}\left\{v_{k}=n \mid \gamma_{k}=M\right\}=C_{M}^{n} p^{n} q^{M-n} \quad(q=1-p), n=0,1, \ldots, M \text {, }
$$

where $\mathrm{p}$ is the probability that a damage is caused to arbitrary container through a stevedoring company's fault;

c) $\Delta_{11}, \Delta_{12}, \ldots, \Delta_{21}, \ldots$ are the i.i.d. random variables with the distribution function (d.f.)

$$
D(x)=\operatorname{Pr}\left\{\Delta_{11} \leq x\right\}
$$

d) the sequences of random variables $v_{1}, v_{2}, \ldots$ and $\Delta_{11}, \Delta_{12}, \ldots$ are mutually independent.

If $\tau$ denotes the constant loading/unloading time of one container, than service time of the $k$ th served ship is the random variable $\gamma_{k} \tau$. We shall consider the steady-state regime of our queueing system functioning and assume that the following stability condition holds true

$$
\lambda<m /\left(\tau \mathrm{E} \gamma_{1}\right),
$$

where $\lambda^{-1}$ is mean inter-arrival time of the ships. 
Let us evaluate the total damage in time interval $(0, t)$ caused to containers by stevedoring company $(\Delta(t))$. Using the above designations we can write

$$
\Delta(t)=\sum_{k=1}^{\omega(t)} \sum_{i=1}^{v_{k}} \Delta_{k i} .
$$

The financial managers of a stevedoring company face the dilemma: to insure or not to insure the possible total damage (16) with the gross risk premium rate $c$ (we assume that the sum insured is $\Delta(t))$. Note that $t$ we consider as the period of insurance policy action.

The simplest criterion of insurance expediency is: the average profit of a stevedoring company in result of the total damage insurance must be positive, i.e. $\mathrm{E}(\Delta(t)-c t)>0$. (18)

Taking into account relations (13)-(17) and applying the theorem of total mathematical expectation to right-hand side of (17), from (18) we have

$$
\mathrm{E} \omega(t) \mathrm{E} v_{1} \mathrm{E} \Delta_{11}>c t,
$$

where

$$
\mathrm{E} \Delta_{1}=\int_{0}^{\infty} x d D(x)<\infty, \mathrm{E} v_{1}=p \sum_{n \geq 1} n \pi_{n}<\infty
$$

For ergodic queue (see (16)) $\mathrm{E} \omega(t)=\lambda t[16,17]$. Therefore, from (19) we obtain

$$
\lambda \mathrm{Ev}{ }_{1} \mathrm{E} \Delta_{11}>c
$$

More precise than criterion (8) is the following

$$
\operatorname{Pr}\{\Delta(t)>c t\} \geq 1-\varepsilon,
$$

where $\varepsilon$ is a given small probability. For application of criterion (21) we need to determine the d.f. of stochastic process $\Delta(t)$.

For the sake of simplicity, we suppose that $\gamma_{k}=N, k=1,2, \ldots$, where $N$ may be interpreted as hold capacity of a ship (in TEU). In other words, we assume that each ship arrives for loading/unloading of exactly $N$ containers. Then by theorem of total probability, taking into account (17), mutual independence of $\omega(t)$ and $v_{1}, v_{2}, \ldots$, we can write 


$$
\begin{gathered}
F(x, t)=\operatorname{Pr}\{\Delta(t) \leq x\}=\operatorname{Pr}\{\omega(t)=0\}+ \\
+\sum_{k=1}^{\infty} \operatorname{Pr}\{\omega(t)=k\} \sum_{n_{1}=0}^{N} \ldots \sum_{n_{k}=0}^{N} \prod_{i=1}^{k} C_{N^{i}}^{n_{1}} p^{{ }^{i}}{ }^{N-n_{i}} D^{\left(n_{1}+\ldots+n_{k}\right)}(x),
\end{gathered}
$$

where $D^{(n)}(x)$ is $n$-multiple convolution of d.f. $D(x)$ with itself, $D^{(0)}(x) \equiv 1$.

Due to the formula (22) the criterion (21) takes the form

$$
F(c t, t)=\operatorname{Pr}\{\omega(t)=0\}+
$$

$$
+\sum_{k=1}^{\infty} \operatorname{Pr}\{\omega(t)=k\} \sum_{n_{1}=0}^{N} \ldots \sum_{n_{k}=0}^{N} \prod_{i=1}^{k} C_{N}^{n_{i}} p^{n_{i}} q^{N-n_{i}} D^{\left(n_{1}+\ldots+n_{k}\right)}(c t) \leq \varepsilon .
$$

In practice, $N$ may be considered as large and $p$ as small quantities. Therefore, the binomial terms in (23) may approximately be substituted for the Poisson distribution. From (23), it follows

$$
\operatorname{Pr}\{\omega(t)=0\}+\sum_{k=1}^{\infty} e^{-a k} \operatorname{Pr}\{\omega(t)=k\} \sum_{n_{1}=0}^{\infty} \ldots \sum_{n_{k}=0}^{\infty} \prod_{i=1}^{k} \frac{a^{n_{i}}}{n_{i} !} D^{\left(n_{1}+\ldots+n_{k}\right)}(c t) \leq \varepsilon,(24)
$$

where $a=N p$.

The Laplace-Stieltjes transform of d.f. (22) on variable $\mathrm{x}$ is given by

$$
\begin{gathered}
\int_{0}^{\infty} e^{-s x} d_{x} F(x, t)=\operatorname{Pr}\{\omega(t)=0\}+ \\
+\sum_{k=1}^{\infty} \operatorname{Pr}\{\omega(t)=k\} \sum_{n_{1}=0}^{N} \ldots \sum_{n_{k}=0}^{N} \prod_{i=1}^{k} C_{N^{i}}^{n_{1}}[p \delta(s)]^{n_{i}}{ }^{N-n_{i}}= \\
=\operatorname{Pr}\{\omega(t)=0\}+\sum_{k=1}^{\infty} \operatorname{Pr}\{\omega(t)=k\}[p \delta(s)+q]^{k N}= \\
=\phi\left([p \delta(s)+q]^{N}, t\right), \quad \operatorname{Re} s \geq 0,
\end{gathered}
$$

where $\delta(s)=\int_{0}^{\infty} e^{-s x} d D(x)$ and $\phi(y, t)=\sum_{k=1}^{\infty} y^{k} \operatorname{Pr}\{\omega(t)=k\},|y| \leq 1, \quad$ is the generating function of stochastic process' $\omega(t)$ distribution.

In particular, from (25) we find 


$$
\begin{aligned}
& \mathrm{E} \Delta(t)=-\left.\frac{\partial}{\partial s} \phi\left([p \delta(s)+q]^{N}, t\right)\right|_{s=0}=N p \mathrm{E} \Delta_{11} \mathrm{E} \omega(t), \\
& \operatorname{Var} \Delta(t)=\left.\frac{\partial^{2}}{\partial s^{2}} \phi\left([p \delta(s)+q]^{N}, t\right)\right|_{s=0}-(\mathrm{E} \Delta(t))^{2}= \\
& =N p\left[\mathrm{E} \Delta_{11}^{2}-p\left(\mathrm{E} \Delta_{11}\right)^{2}\right] \mathrm{E} \omega(t)+\left(N p \mathrm{E} \Delta_{11}\right)^{2} \operatorname{Var} \omega(t) .
\end{aligned}
$$

One more simplification of criterion (21) may be done by application of the Tchebyshev's inequality. Applying this inequality, taken in modified form ${ }^{24}$, we obtain (under condition (18))

$$
\operatorname{Pr}\{\Delta(t)>c t\} \geq \frac{(\mathrm{E} \Delta(t)-c t)^{2}}{\left.\mathrm{E} \Delta^{2}(t)\right)} .
$$

Hence, the criterion (21) may be reduced to the simple inequality

$$
\frac{(\mathrm{E} \Delta(t)-c t)^{2}}{\mathrm{E} \Delta^{2}(t)} \geq 1-\varepsilon
$$

For application of the criteria (23), (24), (26) it is necessary to find out the probabilistic distribution of process $\omega(t)$. It may be found by the methods of queueing theory ${ }^{25,26}$. Below, two particular cases of queue $\mathrm{GI} / \mathrm{G} / m$ will be considered for which this distribution is known.

1) Queue of $M / D / \infty$ type, i.e. with infinite number of servers, the Poisson input with the rate $\lambda$, and constant service time. Such queueing system is good approximation to multi-server queue if $\lambda N \tau<<m$. That is, there is no the queue of ships waiting for beginning of loading/unloading. As it is $\operatorname{known}^{27},{ }^{28}$,

24 Feller W. (1984) Vvedenie v Teoriyu Veroyatnostej i Ee Primeneniya [An Introduction to Probability Theory and Its Application]. V. 2. Moscow: Mir. (in Russian)

25 Gnedenko B. V., Kovalenko I. N. (2005) Vvedenie v Teoriyu Massovogo Obsluzhivaniya. 3d Ed. [An Introduction to Queueing Theory]. Moscow: KomKniga. (in Russian)

26 Kleinrock L. (1979) Teoriya Massovogo Obsluzhivaniya [Queueing Theory]. Moscow: Mashinostroenie. (in Russian)

27 Gnedenko B. V., Kovalenko I. N. (2005) Vvedenie v Teoriyu Massovogo Obsluzhivaniya. 3d Ed. [An Introduction to Queueing Theory]. Moscow: KomKniga. (in Russian)

28 Kleinrock L. (1979) Teoriya Massovogo Obsluzhivaniya [Queueing Theory]. Moscow: Mashinostroenie. (in Russian) 
for such system (in equilibrium) the flow of served customers (in our case, ships after loading/unloading) is Poisson, as well

$$
\operatorname{Pr}\{\omega(t)=k\}=\frac{(\lambda t)^{k}}{k !} e^{-\lambda t}, k=0,1,2, \ldots
$$

and, consequently, $\operatorname{Var} \omega(t)=\mathrm{E} \omega(t)=\lambda t$. In this case the inequality (11) takes the following form

$$
e^{-\lambda t}\left[1+\sum_{k=1}^{\infty} \frac{(\lambda t)^{k}}{k !} \sum_{n_{1}=0}^{N} \ldots \sum_{n_{k}=0}^{N} \prod_{i=1}^{k} C_{N^{i}}^{n_{i}} p^{n_{i}} q^{N-n_{i}} D^{\left(n_{1}+\ldots+n_{k}\right)}(c t)\right] \leq \varepsilon .
$$

From (27), it follows also that

$$
\left.\phi[p \delta(s)+q]^{N}, t\right)=\exp \left\{-\lambda t\left[1-(p \delta(s)+q)^{N}\right]\right\} .
$$

For inversion of this expression the known numerical methods of the Laplace transform inversion may be used ${ }^{29}$.

The criterion (28) is too hard for calculations. Note that in this case the process

$$
\Delta(t)-c t
$$

is the compound Poisson process with the drift $c^{30}$. Therefore if $t \rightarrow \infty$, we can apply the central limit theorem for such kind of stochastic processes ${ }^{31}$. Hence, instead of (21), we have as $t \rightarrow \infty$

$$
P\{\Delta(t)-c t \leq 0\} \approx N(R \sqrt{t}) \leq \varepsilon,
$$

where

$$
R=\left(c / \mathrm{E} \Delta_{11}-\lambda N p\right)\left\{\lambda N p\left[\mathrm{E} \Delta_{11}^{2}+(N-1) p\left(\mathrm{E} \Delta_{11}\right)^{2}\right]\right\}^{1 / 2} ;
$$

$N(x)$ is the standard normal distribution with zero mean and variance equals to unity.

${ }^{29}$ Krylov V. I., Skoblya N. S. (1968) Spravochnik po Chislennomu Obrasheniyu Preobrazovaniya Laplasa [Handbook on Numerical Inversion of the Laplace Transform]. Minsk: Nauka i Technika. (in Russian)

${ }^{30}$ Feller W. (1984) Vvedenie v Teoriyu Veroyatnostej i Ee Primeneniya [An Introduction to Probability Theory and Its Application]. V. 2. Moscow: Mir. (in Russian)

${ }^{31}$ Feller W. (1984) Vvedenie v Teoriyu Veroyatnostej i Ee Primeneniya [An Introduction to Probability Theory and Its Application]. V. 2. Moscow: Mir. (in Russian) 
Let us demonstrate the application of criterion (29) for real initial data. Put $\lambda=5$ ships per month, $t=25$ months, $p=0,001$, and assume that

$$
\mathrm{E}^{\Delta_{11}^{2}=\left(\mathrm{E}^{\Delta_{11}}\right)^{2} .}
$$

The results of probability calculations in the formula (29) for different values of $N p$ and ratio $c / E \Delta_{11}$ are shown in the Table.

Table

\begin{tabular}{|c|c|c|c|c|c|}
\hline$c / \mathrm{E}^{\Delta_{11}}$ & 0,15 & 0,20 & 0,25 & 0,30 & 0,35 \\
\hline 0,10 & 0,0436 & 0,0721 & 0,1112 & 0,1635 & 0,2327 \\
\hline 0,15 & 0,0092 & 0,0150 & 0,0244 & 0,0384 & 0,0582 \\
\hline 0,20 & 0,0021 & 0,0035 & 0,0058 & 0,0092 & 0,0140 \\
\hline 0,25 & 0,0006 & 0,0009 & 0,0015 & 0,0024 & 0,0037 \\
\hline
\end{tabular}

From these results, it follows that insurance is expedient, for example, if $N p=0,1, c / \mathrm{E} \Delta_{11} \leq 0,2$ or $N p>0,1, c / \mathrm{E} \Delta_{11} \leq 0,3$ because the probability in (29) is sufficiently small in these cases.

2) One-server queue of $M / D / 1$ type, i.e. with the Poisson input and constant service time. For such system the following result is valid:

$$
\begin{gathered}
\phi^{*}(y, \theta) \equiv \int_{0}^{\infty} e^{-\theta t} \phi(y, t) d t= \\
=\phi_{0}^{*}(y, \theta)\left[1+\frac{\lambda\left(1-z_{0}\right)\left(1-e^{-\theta N \tau}\right)}{\theta\left(1-y e^{-\theta N \tau}\right)}\right]-\frac{\lambda\left(1-e^{-\theta N \tau}\right)}{\theta^{2}\left(1-y e^{-\theta N \tau}\right)} \times \\
\times\left[(1-y) e^{-\theta N \tau}+\frac{1}{y}(1-\rho)\left(1-z_{0}\right) \frac{z_{0}-y e^{-\lambda\left(1-z_{0}\right) N \tau}}{\left.z_{0}-e^{-\lambda\left(1-z_{0}\right) N \tau}\right]+\frac{\rho}{\theta},}\right.
\end{gathered}
$$

where $\rho=\lambda N \tau<1$;

$$
\Phi_{0}^{*}(y, \theta)=\frac{1-\rho}{\theta\left(\theta+\lambda-\lambda z_{0}\right)}\left[\theta+\frac{\lambda\left(1-z_{0}\right) y e^{-\lambda\left(1-z_{0}\right) N \tau}\left(1-e^{-\theta N \tau}\right)}{e^{-\lambda\left(1-z_{0}\right) N \tau}-z_{0}}\right]
$$

$z_{0}$ is the unique root of the equation 


$$
z_{0}=y \exp \left[-\left(\theta+\lambda-\lambda z_{0}\right) N \tau\right]
$$

in the domain $|y| \leq 1, \operatorname{Re} \theta>0$. The formula (16) may be derived with the help of the theory of linear Markovian processes ${ }^{32}$.

With the help of relation (28) we can determine $\operatorname{Var} \omega(t)$ and then use the criterion (26).

\section{CONCLUSIONS}

In result of above investigation the following conclusions may be done:

1) the main feature of risk-management problems in sea port is: first of all they must be aimed at the protection of financial state of operator of stevedoring or surveying companies but not an insurance company;

2) the formal procedure is worked out in the terms of SSC theory for general cargo physical state detection by surveying company before its loading on a ship;

3) the evaluation of main costs of surveying company is done related to realization of SSC procedure, including the cost concerning risk of too big number of defected cargo units left in non inspected quantity of cargo;

4) the objective functions are formulated for SSC problem - profits of a surveying company in the case of insurance and noninsurance of above risk and the necessary restrictions are formulated for optimal sampling plan;

5) the partly discrete nonlinear stochastic optimization problem is formulated: its solving allow us to substantiate the expediency of insurance of surveying company risk in respect too big number of defected cargo units loaded on the ship;

6) the results obtained allow us consider more general statement of problem under examination, including inspection of cargo state for several ships arriving in port for loading during the given period of time;

7) the real problems of risk-management concerning the port operator's (or stevedoring company's) activity is formulated and solved with application of mathematical risk theory. In most cases these problems may not be solved by standard theoretical methods from the risk theory and require use the combination of different fields of applied probability, for example, ruin theory, queueing and reliability theories, theory of storage processes, etc. This is necessary for modeling the port's operational activity side by side with the corresponding financial processes. For modeling the port's terminal activity the models of some classical queueing systems were used, namely, systems of $\mathrm{M} / \mathrm{D} / 1, \mathrm{M} / \mathrm{D} / \infty$ type. Such formal interpretation of port terminal is needed for

${ }^{32}$ Postan M. Ya. (2006) Ekonomiko-Matematicheskie Modeli Smeshannych Perevozok [Economic-Mathematical Models of Multimodal Transport]. Odessa: Astroprint. (in Russian) 
determination of distribution of containers numbers transshipped at terminal during the fixed time interval. The formulation and solving corresponding problems in the terms of risk theory may increase the financial stability of stevedoring company.

\section{SUMMARY}

The methods of insurance risks expediency during the cargo transshipment in sea port are worked out: for surveying company's for physical state inspection of cargo before it loading on a ship and for stevedoring company's responsibility for safety of containers under their transshipment at port's terminal. For the first type of risk evaluation by surveying company the methods of statistical sampling control (SSC) of cargo's physical state were proposed. Corresponding risk is related to very big number of defected cargo units loaded on a ship. In result of this approach the problem of optimal sampling plan finding was formulated as a partly discrete optimization problem with the objective function maximum of expected profit of surveying company taking into account its cost directed on insurance of its risk. Furthermore, the criterion of insurance of risk expediency of loading on the ship too big number of defected cargo units is worked out. For the second type of risk evaluation the methods of queueing theory were used for representation of a terminal as the multi-server queueing system of $\mathrm{GI} / \mathrm{G} / m$ type for its functioning and corresponding process of containers' damage modeling. The functioning of above queueing system is considered in equilibrium. In result of such modeling it is possible to find out the probabilistic distribution of containers damage value. The comparison was done the stevedoring company's possible insurance expenditures and random value of transshipped containers' total damage (sum insured) for a given period of time. In result of modeling the criterion of insurance expediency of port's operator risk was found.

\section{REFERENCES}

1. Balobanov A. O. (2010) Organizacionno-pravovye aspekty syurvejerskoj deyatelnosti [Organizational-legislative aspects of surveying activity]. Odessa: Feniks. (in Russian)

2. Belyaev Yu. K. (1975) Veroyatnostnye metody vyborochnogo kontrolya [Probabistic method of sampling control]. Moscow: Nauka. (in Russian)

3. John P.W.M. (1990) Statistical Methods in Engineering and Quality Assurance. New York: Wiley. 
4. Juran J. M., Gryna F. M. (1993) Quality Planning and Analysis, $3^{\text {rd }}$ ed., New York: McGraw-Hill.

5. Rose F. D. (2012) Marine Insurance: Law and Practice (2012) $2^{\text {nd }}$ Ed., London: Informa Law.

6. Postan M. Ya., Podchinok I. V. (2004) Ob odnom metode postroeniya optimalnogo plana vyborochnogo kontrolya sostoyaniya gruza v portu [On a method of optimal sample plan for cargo technical state finding in port]. In: Methods and Means of Transportation Systems Development. Collection of Scientific Papers. Odessa: Odessa National Maritime University. Issue 7, pp. 5-17. (in Russian)

7. Podchinok I. V. (2005) Sravnitelnyj Analiz Razlichnyh Planov Vyborochnogo Kontrolya Sostoyaniya Gruza v Portu [Comparative Analyses of Different Plans of Sampling Control of Cargo State in Port]. In: Methods and Means of Transportation Systems Development. Collection of Scientific Papers. Odessa: Odessa National Maritime University. Issue 9, pp. 113-122. (in Russian)

8. Moskvichenko I. M., Stadnik V. G. (2013) Statystychni Metody Vybirkovogo Kontrolyu Stanu Vantazhu v Portu [Statistical Methods of Sample Control of Technical State of Cargo in Port]. Technology Audit and Production Reserves. №5/3 (13), pp. 30-33. (in Ukrainian)

9. Postan M. Ya., Balobanov A. O. (2011) Method of Evaluation of Insurance Expediency of Stevedoring Company's Responsibility for Cargo Safety. In: Methods and Algorithms in Navigation and Safety of Sea Transportation. Eds. A. Weintrit and T. Neumann. CRC Press, pp. 33-36.

10. Postan M. Ya., Poizner M. B. (2013) Method of Assessment of Insurance Expediency of Quay Structures' Damage Risks in Sea Ports. In: Marine Navigation and Safety of Sea Transportation. Maritime Transport and Shipping. Eds. A. Weintrit, T. Neumann. Boca Raton-London-New YorkLeiden: CRC Press, pp. 123-127.

11. Feller W. (1984) Vvedenie v Teoriyu Veroyatnostej i Ee Primeneniya [An Introduction to Probability Theory and Its Application]. V.2. Moscow: Mir. (in Russian)

12. Saaty T. L. (1970) Celochislennye Metody Optimizacii i Svyazannye s Nimi Problemy [Optimization in integers and related extremal problems]. Moscow: Mir. (in Russian)

13. Brown R. H. (1985-1993) Marine Insurance: Vol. I. Principles and Basic Practice; Vol.II. Cargo Practice; Vol. III. Hull Practice, London: Witherby Publishers.

14. Grandell J. (1992) Aspects of Risk Theory. Berlin-Heidelberg-New York: Springer.

15. Asmussen S. (2001) Ruin Probabilities, World Scientific, SingaporeNew Jersey-London-Hong Kong: World Scientific. 
16. Gnedenko B.V., Kovalenko I. N. (2005) Vvedenie v Teoriyu Massovogo Obsluzhivaniya. 3d Ed. [An Introduction to Queueing Theory]. Moscow: KomKniga. (in Russian)

17. Kleinrock L. (1979) Teoriya Massovogo Obsluzhivaniya [Queueing Theory]. Moscow: Mashinostroenie. (in Russian)

18. Krylov V. I., Skoblya N.S. (1968) Spravochnik po Chislennomu Obrasheniyu Preobrazovaniya Laplasa [Handbook on Numerical Inversion of the Laplace Transform]. Minsk: Nauka i Technika. (in Russian)

19. Postan M. Ya. (2006) Ekonomiko-Matematicheskie Modeli Smeshannych Perevozok [Economic-Mathematical Models of Multimodal Transport]. Odessa: Astroprint. (in Russian)

\section{Information about the authors: Postan M. Ya., DSc, Prof.,} Head of the Department of Management \& Marketing, Odessa National Maritime University 34, Mechnikov str., Odessa, 65029, Ukraine ORCID ID: orcid.org/0000-0003-4891-3063

Balobanov O. O., $\mathrm{PhD}$, Prof., Head of the Department of Transport Law, Odessa National Maritime University 34, Mechnikov str., Odessa, 65029, Ukraine ORCID ID: orcid.org/0000-0002-2586-015X 